\title{
Heredity of resistance to Sclerotinia sclerotiorum in sunflowers. III. Study of reactions to artificial infections of roots and cotyledons
}

\author{
D Tourvieille de Labrouhe*, F Vear \\ INRA, Laboratoire du Tournesol, Domaine de Crouelle, 63039 Clermont-Ferrand Cedex, France
}

(Received 15 September 1989; accepted 13 February 1990)

\begin{abstract}
Summary - Reactions of sunflower plants to infections of tap roots with Sclerotinia sclerotiorum sclerotia and of cotyledons with ascospore suspensions were observed. The study was made on the parental inbred lines and F1 hybrids of a factorial cross of 6 male sterile and 6 restorer lines. For root attack, there were significant genotypic differences in the percentages of plants showing symptoms. There were significant parental effects and no interactions. General combining ability appeared greater than specific combining ability. The significant correlation between reactions of inbred lines and their hybrids indicates the possibility of setting up breeding programmes with early selection for root resistance and subsequent obtention of resistant parental lines and breeding of hybrids with resistance to root attack. In contrast, whilst there were significant genetic differences in delay in symptom appearance after infection of cotyledons, specific combining ability far exceeded general combining ability and observations of inbred lines provided no indication of the behaviour of their hybrids. Comparisons with earlier results concerning Sclerotinia infection of capitula and stems indicates that resistance to Sclerotinia in different parts of the sunflower plant is largely under separate control. It does not appear possible to measure resistance of adult plants by tests on seedlings.
\end{abstract}

Sclerotinia / combining ability / additivity / ascospore / interaction / correlation / heritability

Résumé - L'hérédité de la résistance au Sclerotinia sclerotiorum chez le tournesol. Ill. Étude des réactions à des infections artificielles sur racines et sur cotylédons. L'article décrit le comportement de différents génotypes de tournesol en réponse à des contaminations des racines par des sclérotes de Sclerotinia sclerotiorum et à des infections des cotylédons à partir de suspensions d'ascospores. Cette étude est réalisée sur des lignées parentales et les hybrides $F_{1}$ d'un plan factoriel de croisement entre 6 lignées mâle-stériles B11A3, 62, SD, GH, GU, F10 et 6 lignées parentales mâles HA61, Rha274, Rha266, V135, PAC1, PRS5. Pour le test racinaire, qui consiste à infecter les plantes en plaçant $0,5 \mathrm{~g}$ de petits sclérotes au voisinage du pivot au stade "bourgeon étoilè», on observe entre génotypes des différences significatives concernant le taux de plantes qui montrent des symptómes de flétrissement. Ces taux varient de $47,78 \%$ à $93,33 \%$ pour les lignées (tableau I) et de $56,67 \%$ à $100 \%$ pour les hybrides (tableau II). II existe un effet parental significatif $\left(F_{\text {femelle }}=3,66\right.$ et $\left.F_{\text {male }}=2,97\right)$ mais pas d'interaction $\left(F_{\text {interaction }}=1,40\right)$. L'aptitude générale à la combinaison (AGC) parait plus importante que l'aptitude spécifique à la combinaison (ASC). Le coefficient de corrélation entre les lignées et les moyennes de leurs hybrides $\left(r=0,79^{* *}\right)$ montre qu'il est possible de sélectionner précocement pour la résistance aux attaques racinaires et ainsi d'obtenir des lignées parentales résistantes qui donneront des hybrides résistants au niveau des racines. Pour le test sur cotylédons, qui consiste à infecter des plantules avec une suspension de spores, après avoir blessé les cotylédons par le froid, les différences entre génotypes, dans la vitesse de destruction des plantules, sont significatives. Le temps nécessaire à la destruction d'un génotype varie de $5,59 \mathrm{j}$ à $7,38 \mathrm{j}$ pour les lignées (tableau III) et de 6,28 j à 10,50 j pour les hybrides (tableau IV). Contrairement à ce qui se passe pour le test racinaire, l'ASC pour le test sur cotylédon est supérieure à l'AGC (tableau V). Le coefficient de corrélation entre les lignées et les moyennes de leurs hybrides $(r=-0,04$ NS) montre qu'il n'est pas possible de prédire la valeur d'un hybride par le comportement de ses lignées parentales. La comparaison de ces résultats avec ceux concernant les attaques sur capitule ou sur tige (tableau $V$ ) ne montre aucune corrélation entre les réponses aux différents tests. Les résistances au Sclerotinia des différents organes du tournesol sont contrôlées par des gènes distincts et il n'est pas envisageable de tester la résistance qui s'exprime au stade adulte par des tests précoces réalisés sur plantule.

Sclerotinia / ascospore / interaction / corrélation / héritabilité / aptitude à la combinaison

\footnotetext{
* Correspondence and reprints
} 


\section{INTRODUCTION}

Sclerotinia sclerotiorum (Lib) de Bary causes considerable losses in many of the areas where sunflowers are grown. In Europe and Argentina, capitulum attack causes the greatest damage (Regnault et al, 1976; Stinziani and Kesteloot, 1988), whereas in North America most yield loss results from root and basal stem attack (Gulya, 1989).

Earlier studies (Robert et al, 1987; Vear and Tourvieille, 1988a) showed that resistance of sunflower to capitulum attack is polygenic, and that additive effects are predominant. For capitulum resistance, the per se value of inbred lines measured by artificial infections with ascospores or mycelium provides a good indication of the level of resistance that will be shown by their hybrids. Vear and Tourvieille (1984) also showed that these artificial infections are satisfactory in programmes breeding for Sclerotinia resistance.

Thuault and Tourvieille (1988) demonstrated that Sclerotinia resistance in sunflower is not strain specific, but that the reaction of a genotype varies according to the part of the plant infected. Tests of capitulum resistance do not provide any information as to the level of resistance to other forms of attack, for example root or terminal bud. It is therefore necessary to develop tests adapted to each form of the disease.

Root attack may be expected to increase in importance since the level of infestation with Sclerotinia of sunflower growing areas is rising. The number of crops that Sclerotinia can infect is large (eg, rape, soyabean) and the use of rotations, which, while economically satisfactory, involve frequent presence of susceptible crops, multiply the risks of Sclerotinia root infection in areas with insufficient summer rainfall to make capitulum attack a problem (Lamarque, 1985).

This article describes artificial infections on young plants, on roots and also on cotyledons at the seedling stage. For root infection, the test used had already been shown to give results similar to those observed after natural attacks (Tourvieille and Vear, 1984). Infections of cotyledons were first observed in the field in 1986 (Robert et al, 1987). They were observed after a cold period $\left(-4^{\circ} \mathrm{C}\right.$ at night) during the seedling stage, followed by a mild humid period. The cold probably caused lesions on the cotyledons, whilst the mild humid weather permitted Sclerotinia ascospore production and their germination on the necrotic sunflower tissues. In the present study, artificial infections were induced in plants raised in a growth chamber (Tourvieille and Vear, 1986).

\section{MATERIALS AND METHODS}

\section{Sunflower genotypes}

The material used in the studies reported by Robert et al (1987) and Vear and Tourvieille (1988a) chosen to represent the known range of reaction to Sclerotinia was also used for the present work:

- six female parents: (1) B11A3, (2) 62, (3) SD, (4) $\mathrm{GH},(5) \mathrm{GU}$ and (6) F10. B11A3 and $\mathrm{F} 10$ have genic male sterility, and the other 4 lines cytoplasmic male sterility. No distinction was made between male fertile and male sterile plants, since the tests described in this article were made before flowering;

- six male parents: (1) HA61, (2) Rha274, (3) Rha266, (4) V135, (5) PAC1 and (6) PRS5. HA61 and $\mathrm{V} 135$ are male sterility maintainers; the other lines are male fertility restorers;

- 36 hybrids from a factorial cross of the parents, for the root test. The hybrid $B 11 \mathrm{~A} 3 \cdot \mathrm{V} 135$ was lacking for the cotyledon tests.

\section{S sclerotiorum isolates}

\section{"Sclerotia" tests on roots}

A mixture of sclerotia was obtained from production and used both in vitro (Petri dish cultures) and in vivo (capitulum and stem infections), using 2 agressive isolates, SS1 and SS20 (Thuault and Tourvieille, 1988). Since their production, 6 or 18 months before, the sclerotia has been maintained in a cold chamber at $4^{\circ} \mathrm{C}$.

\section{"Ascospore" test on cotyledons}

In the absence of any apparent interaction between Sclerotinia and sunflower genotypes (Thuault and Tourvieille, 1988), a mixture of ascospores obtained from sclerotia of highly varying origin was used.

\section{Infection methods}

\section{Sclerotia test on roots}

The method used was adapted from that described by Tourvieille and Vear (1984). One gram of small sclerotia (weighing $0.05-0.1 \mathrm{~g}$ ) were placed $5-10 \mathrm{~cm}$ below the soil surface in contact with the tap root of sunflower plants at the early flower bud stage. An irrigation of $30 \mathrm{~mm}$ was carried out each week, except when rainfall provided this quantity of water. 
Susceptibility was determined by the number of plants which showed wilting symptoms. After each observation, the plants with symptoms were removed in order to limit contamination of neighbouring plants and infestation of the field. These observations were continued twice a week until physiological maturity on 3 replications of 10 plants of each genotype, placed in a randomised block design.

\section{"Ascospore" test on cotyledons}

This method was described by Tourvieille and Vear (1986). It consisted of wounding parts of the cotyledons of seedlings with one pair of true leaves, using forceps soaked in liquid nitrogen. Three $h$ later, the seedlings were infected with a suspension (in water) of ascospores (100 spores $/ \mathrm{mm}^{3}$ ). They were then maintained in saturated conditions at $18^{\circ} \mathrm{C}$ and with a $16 \mathrm{~h}$ day in a growth chamber. Observations were made of symptom appearance and wilting, which corresponds to extension of Sclerotinia onto the hypocotyl. Observations were made twice a day and the results are given as duration of the latency period (duration infection-symptoms) in days. A long duration was considered as indicative of a good level of resistance. There were 2 replications each of 20 plants.

\section{Estimation of heritability}

Additive effects, comparison of general and specific combining ability and correlations between parents and hybrids were made according to the methods described by Robert et al (1987) and Vear and Tourvieille (1988a).

\section{RESULTS}

\section{Sclerotia tests on roots}

Maintenance of humid soil conditions by regular irrigations, favorable for root infection, led to $84.1 \%$ of plants showing symptoms before physiological maturity. The level of attack varied among the inbred lines (table I) between $47.8 \%$ for PAC1 and $93.3 \%$ for Rha 266 . Of the hybrids (table II), 62.PAC1 showed the best level of resistance with $56.7 \%$ attack. Four hybrids were entirely destroyed: B11A3.Rha274, GH・V135, B11A3.PRS5 and GU.PRS5. The inbred lines showed on average less attack than the hybrids, but their results were more variable. The results being percentages, the analyses of variance were carried out after square root-arc sine transformations. Differences between inbred lines were just below the significance level; between hybrids they were highly significant. In neither case were there any significant block effects. A factorial analysis carried out on the hybrids showed highly significant parental effects ( $F$ female $=3.66 ; F$ male $=2.97$ ) and no interactions $(F$ interaction $=1.40)$. The ratio comparing general and specific combining ability variances is 1.57 , indicating that additive effects were the more significant.

The regression between inbred lines and their hybrids is highly significant. The regression coef-

Table I. Sclerotia test on roots. Percentage attack on inbred lines. Means of 3 replications. CV $=20.53 \% ; F$ genotypes = $1.94(11 / 17 \mathrm{df})(\mathrm{NS}) ; \mathrm{F}$ repetitions $=0.44(2 / 17 \mathrm{df})(\mathrm{NS})$.

$\begin{array}{cc}\text { \% observed } & \text { Transformed } \\ P & \text { data } \\ & \text { arc sine } P\end{array}$

$\begin{array}{lllll}\text { Females } & 1 & \text { B11A3 } & 88.57 & 73.74 \\ & 2 & 62 & 50.74 & 46.31 \\ & 3 & \text { SD } & 89.26 & 70.87 \\ & 4 & \text { GH } & 89.63 & 71.22 \\ \text { Males } & 5 & \text { GU } & 85.93 & 71.77 \\ & 6 & \text { F10 } & 67.88 & 60.71 \\ & & & & \\ & 1 & \text { Ha61 } & 66.67 & 55.07 \\ & 2 & \text { Rha274 } & 57.88 & 49.56 \\ & 3 & \text { Rha266 } & 93.33 & 81.14 \\ & 4 & \text { PAC1 } & 81.52 & 69.72 \\ & 5 & \text { PRS5 } & 47.78 & 43.76 \\ & 6 & & 68.18 & 55.94\end{array}$


Table II. Sclerotia test on roots. Percentage attack on hybrids and parental effects. Transformed means from 3 replications (in brackets: observed data). Isd $(5 \%)$ hybrids $=20.77 ; \mathrm{CV}=14.53 \%$; Isd $(5 \%)$ parental effects $=3.39$; $\mathrm{F}$ genotypes $=2.06(35 / 107 \mathrm{df}){ }^{* *} ; \mathrm{F}$ replication $=2.56(2 / 107 \mathrm{df})(\mathrm{NS})$.

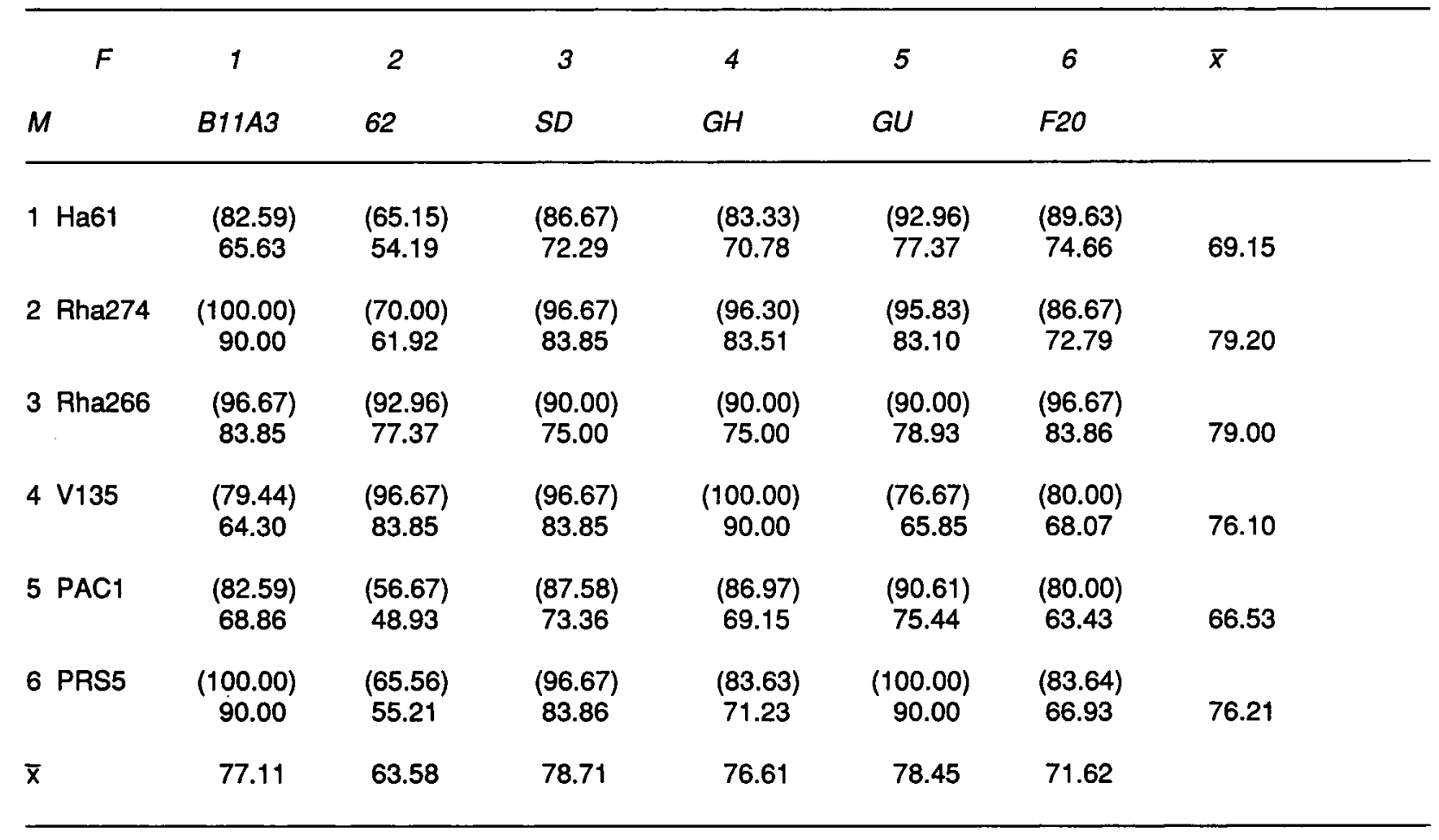

ficient $R=0.58$ indicates that the resistance to root attack has a relatively good level of heritability.

The correlation coefficient between inbreds and the mean of their hybrids, $r=0.79^{\star *}$, indicates that the value of hybrids can be predicted from the per se value of their parents with a determination of $63 \%$.

\section{Ascospore test on cotyledons}

The results showed highly significant differences in behaviour between both inbred lines (table III) and hybrids (table IV). Of all the genotypes, HA61 was clearly the most susceptible, with a mean latency duration of 5.6 days, whereas for all the other genotypes, this duration exceeded 6 days. The best inbreds were SD and GH, taking more than 7 days before destruction. With a mean latency period of 6.7 days, the inbreds appear generally more susceptible than the hybrids (mean $=7.2$ days). The best hybrids were $62 \cdot P A C 1$ and $62 \cdot P R S 5$, with respectively 10.5 and 10.3 days latency.

In the absence of the hybrid B11A3.V135, 3 factorial analyses were made (table $\mathrm{V}$ ), all giving similar results. In all cases, whilst the female ef- fects are significant, the male effects are not. Interactions are highly significant and the ratio comparing GCA and SCA variances is very small, indicating few evident additive effects and preponderant specific combining ability.

This result is confirmed by the absence of any significant regression between parents and hybrids. The correlation coefficient between the per se value of inbreds and the mean of their hybrids ( $r=-0.04 \mathrm{NS}$ ) shows that it is not possible to pre-

Table III. Ascospore test on cotyledons: delays in symptom appearance on inbred lines (expressed in days from infection to wilting, means of 2 replications). Isd $(5 \%)=0.44 ; \mathrm{CV}=3.1 \% ; \mathrm{F}$ genotypes $=8.41(11 / 24$ df) ${ }^{\star}$.

\begin{tabular}{llll}
\hline Females & 1 & B11A3 & 6.69 \\
& 2 & 62 & 6.68 \\
& 3 & SD & 7.38 \\
& 4 & GH & 7.38 \\
& 5 & GU & 6.72 \\
Males & 6 & F10 & 6.92 \\
& & & \\
& 1 & Ha61 & 5.59 \\
& 2 & Rha274 & 6.66 \\
& 3 & Rha266 & 6.47 \\
& 4 & V135 & 6.60 \\
& 5 & PAC1 & 6.41 \\
& 6 & PRS5 & 6.65 \\
\hline
\end{tabular}


Table IV. Ascospore test on cytoledons: delay in symptom appearance on hybrids and parental effects (expressed in days from infection to wilting, mean of 2 replications). Isd (5\%) hybrid $=1.79 ; C V=12.20 \%$; Isd $(5 \%)$ parental effect $=$ 1.32; F hybrid $=3.02(34 / 35 \mathrm{df}){ }^{* *} ;()=$ calculated value for missing hybrid.

\begin{tabular}{llllllll}
\hline \multicolumn{1}{c}{$F$} & 1 & 2 & 3 & 4 & 5 & 6 & $\bar{x}$ \\
$M$ & $B 11 A 3$ & 62 & $S D$ & $G H$ & $G U$ & $F 10$ & \\
\hline 1 Ha61 & 6.40 & 6.66 & 9.50 & 7.92 & 6.83 & 6.67 & 7.33 \\
2 Rha274 & 6.75 & 8.73 & 7.46 & 6.38 & 6.53 & 9.00 & 7.48 \\
3 Rha266 & 6.66 & 6.54 & 7.40 & 6.53 & 6.57 & 6.28 & 6.66 \\
4 V135 & $6.85)$ & 7.50 & 7.22 & 7.30 & 6.68 & 6.53 & 7.02 \\
5 PAC1 & 6.90 & 10.50 & 6.42 & 7.09 & 6.80 & 7.25 & 7.49 \\
6 PRS5 & 6.54 & 10.25 & 6.68 & 6.77 & 6.51 & 7.18 & 7.32 \\
$\bar{x}$ & 6.68 & 8.31 & 7.45 & 7.00 & 6.65 & 7.15 & \\
\hline
\end{tabular}

dict the value of hybrids from that of inbreds. For example, 62 , one of the more susceptible lines, gives the 2 most resistant hybrids (62.PAC1, 62.PRS5).

\section{Correlations between resistance tests}

For 30 of the hybrids studied, it was possible to calculate correlation coefficients between the 2 tests described above and other tests reported previously:

- mycelium on hypocotyls in vitro (Robert, 1985);

- mycelium on young stems (Robert et al, 1987);

- mycelium on capitula (Robert et al, 1987);
- ascospores on capitula (Vear and Tourvieille, 1988a);

- observations of semi-natural attack on capitula (Vear and Tourvieille, 1988a).

The coefficients are given in table VI. They confirm earlier results that the responses of sunflower genotypes to different forms of Sclerotinia attack are independent. The significant correlation between the sclerotia test on roots and the ascospore test on cotyledons $(r=-0.575)$ will be discussed below.

\section{DISCUSSION}

\section{Sclerotia test on roots}

The infection technique used is simple and repeatable and thus can be used to judge the re-

Table V. Ascospore test on cotyledons: estimate of heritability of the latency period by factorial analysis of variance on hybrids. $\mathrm{Ff}=\mathrm{F}$ female effect; $\mathrm{Fm}=\mathrm{F}$ male effect; $\mathrm{Fi}=\mathrm{F}$ interaction; $\mathrm{GCA} / \mathrm{SCA}=$ general combining ability variance/specific combining ability variance.

\begin{tabular}{|c|c|c|c|c|c|}
\hline Female parents & Male parents & $F f$ & $F m$ & $F i$ & GCA $S C A$ \\
\hline 123456 & 12356 & $5.88\left(^{* *}\right)$ & 1.64 (NS) & $2.73(* *)$ & 0.26 \\
\hline 23456 & 123456 & $5.61\left(^{* *}\right)$ & 1.67 (NS) & $2.66(* *)$ & 0.18 \\
\hline \multirow[t]{2}{*}{23456} & 12356 & $5.07(* *)$ & 1.59 (NS) & $2.77\left(^{*}\right)$ & 0.13 \\
\hline & & & & Mean & 0.19 \\
\hline
\end{tabular}


Table VI. Correlations between the results of different tests of resistance to Sclerotinia (for 30 hybrids). (1) Measurement of susceptibility level; (2) Measurement of resistance level.

Test

\begin{tabular}{lll} 
& $\begin{array}{l}\text { Sclerotia test } \\
\text { on roots (1) }\end{array}$ & $\begin{array}{l}\text { Ascospore test } \\
\text { on cotyledons (2) }\end{array}$ \\
\hline Mycelium test on capitula (1) & 0.328 (NS) & -0.331 (NS) \\
Ascospore test on capitula (2) & 0.083 (NS) & -0.026 (NS) \\
Natural infection on capitula (1) & 0.305 (NS) & -0.193 (NS) \\
Mycelium test on stems (1) & -0.003 (NS) & -0.079 (NS) \\
Mycelium test on hypocotyls (1) & -0.176 (NS) & 0.064 (NS) \\
Sclerotia test on roots (1) & & $-0.575 *$ \\
\hline
\end{tabular}

Correlation
The highly significant correlation between the action of genotypes, hybrid and inbred, to this form of attack.

However, comparison of the present results with those obtained on the same inbred lines and hybrids by Robert et al (1987) and Vear and Tourvieille (1988a) shows that there is no correlation with any of the measurements of capitulum resistance. Genotypic reaction appears independent for different forms of Sclerotinia attack (Thuault and Tourvieille, 1988). It is thus not possible to determine an overall Sclerotinia reaction from one testing method.

This independence also appears in the mode of heredity of resistance to different forms of attack. Additive effects appear more important than interactions in reaction to root attack, but the ratio GCA/SCA at 1.57, is smaller than for example that for the ascospore test on capitulum, with a mean value of 3.76 (Vear and Tourvieille, 1988a). It may also be noted that the negative correlation between oil content and capitulum resistance to Sclerotinia which has slowed selection programmes for the latter character is not at all evident for root resistance (Vear and Tourvieille, 1988b), further evidence that the different mechanisms and the genes controlling them are involved in the determination of resistance to different forms of attack. Bazzalo et al (1987) demonstrated the importance of the role of lignin in the resistance of stem bases to Sclerotinia, whereas Hemery et al (1987) showed that capitulum resistance to Sclerotinia extension may be in part the result of production of phenolic compounds of the inhibitin type. per se values of inbred lines and those of their hybrid combinations suggests that breeding programmes with selection during early generations or on inbred lines should be reasonably efficient. However, the destructive nature of the test, and the type of observation (\% of plants with symptoms) make single plant selection impractical. Family selection will have to be carried out, either from the F3 or F4 generation in pedigree programmes or half sib or full sib families in a recurrent selection programme with the objective of increasing the frequency of genes providing resistance to root attack.

\section{Ascospore test on cotyledons}

The objective of this test was not only to reproduce a particular form of natural Sclerotinia attack, but also to determine whether this test could provide a useful seedling test in the laboratory to determine resistance to one form or an other of Sclerotinia resistance.

Technically it is relatively straightforward, and takes only 2 weeks to carry out. Results show satisfactory repeatability ( $\mathrm{CV}=12.2 \%)$.

However, in the field in 1986 only a few genotypes were observed with this type of attack, so that no correlation can be calculated between the test and natural attack at present.

Although there are significant genotypic differences for both inbred lines and hybrids, heritability in the sense of additivity appears very weak. 
There are significant differences in female effects, but none for the male parents and the ratio of general to specific combining ability variances at 0.19 indicates that the behaviour of a hybrid genotype depends far more on the specific combination than on the parental lines. The absence of any significant correlation between per se values of inbred lines and values of their hybrids also indicates that breeding programmes for this type of resistance with tests at early generations cannot be proposed.

The absence of any correlation between the responses to this test and those measuring capitulum resistance can be easily explained by the fact that different organs are involved (as with the comparison capitulum-root). However, the absence of any correlation with the tests on hypocotyls or young stems is more surprising, since these tests are also carried out in the laboratory on young plants. The main difference is that the cotyledons are infected after wounding by ascospores, whereas the stems are infected by mycelium explants. This difference could explain the variation in results: wounding with liquid nitrogen can cause a biochemical reaction which stimulates response of sunflower resistance mechanisms. Hemery et al (1987) showed that such a type of wounding increased phenol production in the capitula of certain genotypes, whilst others did not react.

Considering the differences that appear for heritability of reaction level, the significance of the correlation between the results of the sclerotia test and the ascospore test on cotyledons is rather surprising. It appears to result from the behaviour of 2 hybrids, 62.PAC1 and 62.PRS5, which are quite different from the other hybrids, appearing much more resistant to both tests. If they are excluded from the comparison, the correlation drops to a very low level ( $r=-0.10 ; n=$ NS). It may be suggested that these hybrids have specific combinations of the genes giving heritable largely additive resistance to root attack which also interact efficiently to delay symptom appearance in seedlings.

\section{CONCLUSION}

In conclusion, these studies make it possible to plan breeding programmes for resistance to Sclerotinia root attack, based on artificial infec- tions. Selection on families during the course of breeding should provide inbred lines giving hybrids with satisfactory behaviour. In contrast, laboratory tests of Sclerotinia reaction on young plants have not shown their usefulness. Too far removed from natural conditions, they are not representative of highly complex systems of resistance which develop in sunflower plants grown in the field (Tourvieille and Vear, 1984). In addition, the lack of correlation between parents and their progenies makes it difficult to propose their use in screening large collections for unusual gene combinations.

\section{REFERENCES}

Bazzalo ME, Heber EM, Caso OH (1987) Factores fisicos y localizacion anatomica de compuestos tenolicos en relación con la tolerencia de los tallos de girasol (Helianthus annuus) frente a Sclerotinia sclerotiorum, causal de la podredumbre basal. Bull Soc Argentina Bot 25, 197-212

Gulya T (1989) Sunflower disease distribution, incidence and severity in the Dakotas and Minnesota. USDA Agric Res Service (in press)

Hemery MC, Tourvieille D, Jay M, Vear F (1987) Recherche de marqueurs phénoliques impliqués dans la résistance du tournesol au Sclerotinia. Inf Tech CETIOM 101, 20-29

Lamarque C (1985) Evolution permanente de la situation phytosanitaire du tournesol en France. Phytoma Def Cult 367, 20-24

Regnault Y (1976) Répartition des principales maladies du tournesol en France. Proc 7 th Int Sunflower Conf, Krasnodar, URSS, 179-188

Robert N (1985) Approche de l'hérédité des caractères de résistance à Sclerotinia sclerotiorum chez le tournesol. Etude comparative des tests de sélection. DEA Agronomie, Université de Rennes I, France

Robert N, Vear F, Tourvieille D (1987) L'hérédité de la résistance à Sclerotinia sclerotiorum (Lib) de Bary chez le tournesol. I. Etude des réactions à deux tests mycéliens. Agronomie 7, 423-429

Stinziani J, Kesteloot JA (1988) Inoculation methods in the field with Sclerotinia sclerotiorum in sunflower. Proc XIlth Int Sunflower Conf, Novi-Sad, Yugoslavia, $78-83$

Thuault MC, Tourvieille D (1988) Etudes du pouvoir pathogène de huit isolats de Sclerotinia appartenant aux espèces $S$ sclerotiorum, $S$ minor et $S$ trifoliorum sur le tournesol. Int Tech CETIOM 103, 21 . 27

Tourvieille D, Vear F (1984) Comparaison de méthodes d'estimation de la résistance du tournesol à 
Sclerotinia sclerotiorum (Lib) de Bary. Agronomie 4, 517-525

Tourvieille D, Vear F (1986) Sclerotinia : lutte par l'amélioration génétique, la résistance. Déf Vég 238, 16-21

Vear F, Tourvieille $D$ (1984) Recurrent selection for resistance to Sclerotinia sclerotiorum in sunflowers using artificial infections. Agronomie 4, 789-794
Vear F, Tourvieille D (1988a) Heredity of resistance to Sclerotinia sclerotiorum in sunflowers. II. Study of capitulum resistance to natural and artificial ascospore infections. Agronomie 8, 503-508

Vear F, Tourvieille D (1988b) Relations between oil content and resistance to Sclerotinia sclerotiorum in sunflowers. Proc XII Int Sunflower Conf, Novi-Sad, Yugoslovia, 355-360 